\title{
Invasive ctenophore Mnemiopsis leidyi in the Caspian Sea: feeding, respiration, reproduction and predatory impact on the zooplankton community
}

\author{
Galina A. Finenko ${ }^{1}$, Ahmet E. Kideys ${ }^{2,6, *}$, Boris E. Anninsky ${ }^{1}$, Tamara A. Shiganova ${ }^{3}$, \\ Abolghaseem Roohi ${ }^{4}$, Mojgan R. Tabari ${ }^{4}$, Hosseinali Rostami ${ }^{4}$, Siamak Bagheri ${ }^{5}$ \\ ${ }^{1}$ Institute of Biology of the Southern Seas, Nachimov Ave. 2, Sevastopol, Ukraine \\ ${ }^{2}$ Institute of Marine Sciences, Middle East Technical University, Erdemli 33731, Turkey \\ ${ }^{3}$ P.P. Shirshov Institute of Oceanology RAS, 36 Nachimovskiy Pr., Moscow, Russia \\ ${ }^{4}$ Mazandaran Fisheries Research Center, Sari, Iran \\ ${ }^{5}$ Guilan Fisheries Research Center, Anzali, Iran \\ ${ }^{6}$ Present address: Joint Research Center, Institute for the Protection and Security of the Citizen, Ispra, 21020 Varese, Italy
}

\begin{abstract}
The impact of the invasive ctenophore Mnemiopsis leidyi on the zooplankton community of the Caspian Sea was quantified according to food consumption and other major physiological activities (i.e. respiration and reproduction), coupled with field data on population structure. The adverse effects of $M$. leidyi on the zooplankton community during the first years of the invasion were tremendous for the Caspian Sea compared to other regions affected by this ctenophore. The impact was highest in summer, due to high water temperatures and a population size structure in which juvenile ctenophores with mean lengths of 2 to $5 \mathrm{~mm}$ accounted for most of the population. During winter/spring, these ctenophores could consume the available stock of zooplankton in 3 to $8 \mathrm{~d}$, whereas in summer consumption took only $1 \mathrm{~d}$. The computed critical ctenophore biomass that does not affect (decrease) the abundance of mesozooplankton in the Caspian Sea is about $4 \mathrm{~g} \mathrm{~m}^{-3}$ (or $120 \mathrm{~g} \mathrm{~m}^{-2}$, assuming most of the ctenophores occur in the upper $30 \mathrm{~m}$ layer). As is clear from the monitoring data, the M. leidyi biomass in summer in different regions of the Caspian Sea is far in excess of this value. Such a high abundance of ctenophores, if maintained, would constantly keep the nongelatinous zooplankton biomass at very low levels, and, as a consequence, no recovery could be expected in the pelagic fishery.
\end{abstract}

KEY WORDS: Mnemiopsis leidyi $\cdot$ Feeding $\cdot$ Respiration $\cdot$ Reproduction $\cdot$ Predatory impact

\section{INTRODUCTION}

The invasion of the Caspian Sea by the western Atlantic ctenophore Mnemiopsis leidyi (Agassiz) since the late 1990s is a demonstrative phenomenon of the threat of an alien species on the biodiversity and functioning of marine environments. This invasion has already caused enormous economic and environmental impacts on the Caspian ecosystem (Kideys 2002).

The Black Sea was the first impressive example of the damaging impact of this invasive species upon an ecosystem in general and upon the pelagic community in particular. The accidental introduction and subsequent explosion of the ctenophore Mnemiopsis leidyi in the late 1980s resulted in not only a dramatic decrease in the abundance of almost all species preyed on by pelagic fish, but also in disappearance of some species (the copepod Oithona nana, the chaetognath Sagitta setosa) from the zooplankton community (Vinogradov et al. 1992, Kovalev et al. 1998, Shiganova et al. 1998, Kideys et al. 2000). M. leidyi competition with planktonic fish for zooplankton as a food resulted in a remarkable decline in the pelagic fishery during those years (i.e. 1988 to 1992; Kideys 1994, 2002). 
The possibility of this ctenophore invading other neighboring ecosystems, notably the Caspian Sea, was mentioned (Dumont 1995, GESAMP 1997). And, as expected, this species was reported to be in the Caspian Sea by November 1999 (Ivanov et al. 2000). Most probably Mnemiopsis leidyi was transported into the central or southern Caspian from the Black Sea or the Sea of Azov in the ballast waters of ships through the Volga-Don Canal (Ivanov et al. 2000).

Investigations of the new invader to the Caspian Sea in 2000 to 2001 showed that it was found almost everywhere, including the northwestern Caspian, where salinity exceeded 4 ppt (Shiganova et al. 2003). There was an increasing trend in the abundance of Mnemiopsis leidyi in 2001 compared to 2000. In August 2001, the average and maximum biomasses of M.leidyi over the entire middle and southern Caspian Sea were as high as 120 and $351 \mathrm{~g}$ wet weight (WW) $\mathrm{m}^{-2}$, respectively, compared to a mean value of $60 \mathrm{~g} \mathrm{~m}^{-2}$ in the summer of 2000 (Shiganova et al. 2001, Kideys \& Moghim 2003).

Non-gelatinous mesozooplankton in the northern Caspian showed a 5-fold density decrease and a 6 -fold biomass decrease in October 2001, compared with July when Mnemiopsis leidyi was absent; the most considerable decline was in the density of copepods (Shiganova et al. 2001). The most drastic decrease in the zooplankton biomass appeared to be in the southern Caspian, where the highest biomasses of $M$. ledyi have been observed.

The impact of Mnemiopsis leidyi on the Caspian Sea ecosystem is expected to be greater than in the semienclosed Black Sea, as the former is a completely enclosed basin and, hence, has a greater sensitivity to invasion stresses (Dumont 1995). Since M. leidyi is a voracious predator and a competitor with planktivorous fish for zooplankton, a significant decline in catches of the main small pelagic fish (i.e. the kilka Clupeonella spp.) has already been reported for some riparian countries (Kideys et al. 2001a,b). Within 2 yr (2000 and 2001) an almost $50 \%$ decrease in the kilka catches of Iranian fishermen has occurred, with a minimum of 15 million US dollars financial revenue loss (Kideys \& Moghim 2003).

Determination of the food consumption and major physiological rates (i.e. reproduction and respiration) of Mnemiopsis leidyi, along with monitoring the population and its condition in situ, are very important in assessing the impact of this predator on the pelagic community. Here, we attempt to quantify the predatory impact of the alien ctenophore $M$. leidyi on the zooplankton community by studying its feeding and respiration rates in the laboratory, as well as its abundance, biomass and population structure in different regions of the Caspian Sea. In our calculations we examined the case in which mesozooplankton is considered the main food source for M. leidyi, as this species has traditionally been considered to be a carnivore (Baker \& Reeve 1974, Kremer 1979, Mutlu 1999, Finenko \& Romanova 2000). Although there have been a number of experimental studies on the consumption of microplankton prey items by adult and, especially, by larval and post-larval $M$. leidyi (Stanlow et al. 1981, Stoecker et al. 1987, Costello \& Coverdale 1998, Sullivan \& Gifford 2004), their trophic impact on microplankton in the sea has not yet been estimated. An attempt was made recently by Sullivan \& Gifford (2004), on the basis of their experimental values for the clearance rate of early stages of $M$. leidyi and Deason's (1982) ctenophore abundance of $<10 \mathrm{~mm}$ length. This estimation showed the high clearing potential of $M$. leidyi larvae, which, at their maximum abundance, could potentially clear up to $60 \%$ of the water column per day. In addition, we attempted some preliminary calculations to estimate the predatory impact of small $M$. leidyi on the microplankton of the southern Caspian Sea.

\section{MATERIALS AND METHODS}

Chemical composition. Measurements of ctenophore chemical composition were carried out from September to October 2001 using samples from the inshore waters of the southern Caspian Sea (Khazerebad region in the Mazandaran province of Iran). Ctenophores were collected daily with a net (mesh size: $500 \mu \mathrm{m}$ ) and put in large aquaria (20 l volume). All the collected animals were visually checked to be undamaged and maintaining activity typical for their natural behavior. The specimens were delivered to the laboratory within $1 \mathrm{~h}$, where they were sorted using sieves and hand-selection in accordance with their sizes. As a result, the ctenophores were divided into 10 size groups: $1,2,5,10,15,20,25,30,35$ and $40 \mathrm{~mm}$. Pooled samples of about 300 specimens from the smallsized ctenophores ( 1 to $2 \mathrm{~mm}$ ), 10 to 40 specimens from the middle groups ( 5 to $30 \mathrm{~mm}$ ) and 4 to 5 specimens from the large-sized ctenophores ( 35 to $40 \mathrm{~mm}$ ) were taken in triplicate from each individual size group. After carefully removing the adhering water (on nylon mesh with absorbent paper below), the ctenophores were placed into hermetically closed vials and frozen at $-20^{\circ} \mathrm{C}$. The samples were stored in a freezer for up to $10 \mathrm{~d}$ and thawed at ambient temperatures before chemical fixation. From 1 replicate of 0.2 to $0.5 \mathrm{ml}$ volume (0.2 to $0.5 \mathrm{~g} \mathrm{WW}$ ) separate subsamples were taken from freshly thawed homogenate for protein, lipids, carbohydrates and free amino acids (see Table 1). Protein was fixed by $3 \%$ TCA solution, lipids by $2: 1$ (v/v) 
chloroform/methanol (Folch et al. 1957) and carbohydrates and free amino acids by $80 \%$ ethanol (Zaslavsky 1980).

Protein was measured with the Lowry method modified by Hartree using HSA as a standard (Hartree 1972). Amino acids (ninhydrine-positive substances) were measured by the Pochinok method with $\mathrm{D}, \mathrm{L}-\alpha$-alanine as a standard (Kuzmenko 1975). Carbohydrates were determined by the Dubois method with D-glucose as a standard (Dubois et al. 1956). Total lipids were estimated by the method of Amenta (Amenta 1964, Clarke et al. 1992); the standard was triolein/cholesterol (1:1).

Organic matter content in the ctenophores was determined by summing all the organic constituents. Calorific value of the ctenophore tissues was calculated, using standard energy equivalents, to be $5.65 \mathrm{cal}$ $\mathrm{mg}^{-1}$ for protein, $9.45 \mathrm{cal} \mathrm{mg}^{-1}$ for lipids and $4.10 \mathrm{cal}$ $\mathrm{mg}^{-1}$ for carbohydrates (Omori \& Ikeda 1984).

These techniques of biochemical measurements have previously been evaluated (Clarke et al. 1992) and assessed to be reliable for determination of the proximate biochemical composition of gelatinous zooplankton.

Feeding experiments. The ctenophores utilized for feeding experiments were collected in the same region (i.e. Khazarabad) and using the same collection methods as those for chemical analyses; they were subsequently placed in $20 \mathrm{l}$ aquaria. Within 1 to $2 \mathrm{~h}$ after sampling undamaged specimens were very carefully selected from the aquaria for use in the experiments.

The zooplankton prey specimens were collected daily by horizontal tows ( 3 tows each of 10 min duration) using a $100 \mu \mathrm{m}$ net, followed by filtration through a coarse mesh, basically to remove Mnemiopsis leidyi. Prey items consisted mostly of nauplii, copepodites and adults of the copepod Acartia sp. (mixture of A. clausi and $A$. tonsa). Seawater filtered through a $30 \mu \mathrm{m}$ mesh was added to the samples to bring the total volume of containers with zooplankton stock to $1000 \mathrm{ml}$. Prior to the experiments, the number of Acartia was counted 3 times in $10 \mathrm{ml}$ subsamples from the stock container. To ensure an initial concentration of about 100 adult and copepodite Acartia per liter in each experimental container (volume of $5 \mathrm{l}$ ), we added a specific volume (ranging from 85 to $140 \mathrm{ml}$ for the various experiments) that was calculated from the average concentration of Acartia in the stock container. The food concentration ranged from 0.8 to $2.1 \mathrm{mg} \mathrm{l}^{-1}$ of Acartia (adults and copepodites) and from 0.07 to $0.45 \mathrm{mg} \mathrm{l}^{-1}$ of nauplii (see Table 2). These concentrations were within the range of zooplankton biomasses in the Caspian Sea, which, in the summer of 2001, varied between 60 and $700 \mathrm{mg} \mathrm{m}^{-3}$, depending on the region (Shiganova et al. 2004). Experiments with the 3 size groups of M. lei$d y i$ (lengths of $4-5,9-10$ and $15-20 \mathrm{~mm}$ and average wet weights of $0.04,0.22$ and $0.92 \mathrm{~g}$, respectively) in individual containers, were carried out on 4 replicates at $21^{\circ} \mathrm{C}$ during a $6 \mathrm{~h}$ period (between 12:00 and 18:00 $\mathrm{h}$ in most of the experiments) in the dark, to avoid local aggregation of prey and predators. Because there are some diel variations in the in situ feeding rate of M. leidyi (Sergeeva et al. 1990), the timing of our experiments was chosen to obtain the mean daily consumption rate. For experiments, 10 ctenophores from the first size group and 5 ctenophores each from the second and third size groups were added to each container. Two containers with the same initial concentration of zooplankton, but without ctenophores, were used as controls. The container volume, density of predators and duration of the experiments were chosen to obtain a statistically significant feeding response. As has been shown for calanoid copepods, a decrease in the final prey abundance by 30 to $40 \%$ is optimal (Gifford 1993). The abundance of food items in our experimental containers decreased by about 40 to $45 \%$, which is not much more than $40 \%$, and we therefore do not believe that feeding activity changed in response to lowered food concentrations. No change occurred in the control vessels up to the end of the experiment.

After each experiment, ctenophores were removed from the experimental containers and water with zooplankton was filtered through a $30 \mu \mathrm{m}$ mesh to reduce the total volume to $200-250 \mathrm{ml}$. The numbers of different stages of Acartia (nauplii, copepodites and adults) were counted in every container. The average prey biomass $\left(\mathrm{mg} \mathrm{l}^{-1}\right)$ was calculated from numbers and individual weights of each stage in the container. The clearance rate was computed by the difference between the control and the experimental containers at the end of the experiment using the equation:

$$
\mathrm{CR}=V \times\left(\log C_{\mathrm{c}}-\log C_{\mathrm{e}}\right) / 0.4343 \times N \times T
$$

where CR is the clearance rate $\left(\mathrm{ml}\right.$ ind..$\left.^{-1} \mathrm{~h}^{-1}\right), V$ is the volume of the experimental container $(\mathrm{ml}), C_{\mathrm{c}}$ and $C_{\mathrm{e}}$ are the prey concentrations in the control and experimental containers (ind. $\mathrm{ml}^{-1}$ ), respectively, $N$ is the number of Mnemiopsis leidyi, $T$ is time (in hours) and 0.4343 is a coefficient used to change a natural logarithm into a base 10 logarithm. Regression analysis was performed to evaluate clearance rate as a function of body weight using the Microsoft Excel 98 software package.

The consumption rates of Acartia by Mnemiopsis leidyi were calculated from the clearance rate and mean abundance and from the individual weights of different stages (Stage I to V copepodites, males and females; Petipa 1957) in each container. The ration of copepod nauplii consumed was computed by taking into account their total number and mean wet weight (0.002 mg; Petipa 1957). 
Upon completion of the experiment, Mnemiopsis leidyi specimens from each experimental container were measured and their weight was calculated from the equation $W=0.0011 L^{2.34}$, where $W$ is wet weight in grams and $L$ is length in millimeters (Kideys \& Moghim 2003).

Respiration rate. The respiration rate of Mnemiopsis leidyi was measured at an ambient temperature of $24^{\circ} \mathrm{C}$ in the dark in $250 \mathrm{ml}$ volume bottles having 1 to 240 specimens each depending on the ctenophore's size. $M$. leidyi length ranged from 1.2 to $38 \mathrm{~mm}$ and wet weight ranged from 0.0015 to $2.46 \mathrm{~g}$. The experimental and control (without animals) respirometers were incubated for 14 to $15 \mathrm{~h}$; the oxygen concentration decreased $10 \%$ of initial values.

Calculations of the metabolic rates were made from the measured difference in oxygen concentrations in the experimental and control bottles. At the end of the incubation period, oxygen concentrations were measured in subsamples of seawater transferred into $30 \mathrm{ml}$ bottles of biochemical oxygen demand (BOD). Oxygen concentrations were determined by titration using the Winkler method (Omori \& Ikeda 1984).

Reproduction. Forty-seven experiments were performed to study the reproduction rate of Mnemiopsis leidyi. Freshly collected adult specimens of different sizes were placed in the 21 filtered seawater containers and kept in the dark for spawning at 22 to $25^{\circ} \mathrm{C}$. Because spawning in $M$. leidyi takes place at night (Pianka 1974, Zaika \& Revkov 1994), we examined and counted the number of fertilized eggs and early embryos after $24 \mathrm{~h}$, to be sure that spawning was complete. After examination, eggs and embryos were put into incubators (containing filtered water) for hatching at the same temperature 22 to $25^{\circ} \mathrm{C}$, and, after another $24 \mathrm{~h}$, the number of hatched eggs was estimated.

Abundance, biomass and population dynamics. To obtain data on temporal distribution, the ctenophores were collected monthly from shallow waters near Khazerabad, Iran (southern Caspian Sea), during the period from July 2001 to September 2002 (A. E. Kideys \& A. Roohi unpubl. data). The sampling was done using a net $(500 \mathrm{~mm}$ mesh size, with a $50 \mathrm{~cm}$ wide mouth opening) during daytime by vertical hauls from a depth of $5 \mathrm{~m}$ to the surface. Upon retrieval, samples were immediately examined, the ctenophores were counted and their total lengths were measured to the nearest $1 \mathrm{~mm}$; the size-specific abundance of ctenophores (in intervals of $10 \mathrm{~mm}$ ) was estimated. Wet weight was calculated using the regression equation provided earlier in this section. The total biomass was computed as the sum of biomasses of all size groups.

In order to study the spatial distribution of the Mnemiopsis leidyi population in the northern, middle and southern Caspian, samples were taken during a cruise in August 2001. The shallow northern region had a maximum depth of $24 \mathrm{~m}$ at its boundary with the middle Caspian and a minimum depth of $5 \mathrm{~m}$ close to the mouth of the Volga River. The surface-water temperatures varied from 26.6 to $30.9^{\circ} \mathrm{C}$; salinity was $10 \%$ at the southernmost stations and $6 \%$ at the northernmost stations in the northern Caspian.

Hauls were obtained from 23 stations (Fig. 1). The sampling of Mnemiopsis leidyi was carried out using an ichthyoplankton net, with a $50 \mathrm{~cm}$ diameter mouth opening and a $500 \mathrm{~mm}$ mesh size. Samples were collected from near the bottom ( 5 to $24 \mathrm{~m}$ ) to the surface in the northern Caspian and from $20 \mathrm{~m}$ depth (thermocline layer) to the surface in other regions. Simultaneously, mesozooplankton was sampled at 9 stations from $50 \mathrm{~m}$ depth to the surface: at 2 stations in the northern Caspian with Apshtein net $(25 \mathrm{~cm}$ diameter, $95 \mu \mathrm{m}$ mesh size), at 4 stations in the middle and at 3 stations in the southern Caspian with a Juday net $(36 \mathrm{~cm}$ diameter, mesh size $112 \mathrm{~mm}$ ). Samples were immediately fixed using $4 \%$ formaldehyde solution and analyzed using standard methods (Kiselev 1969).

Ctenophore biomass was calculated from the abundance and from the mean wet weight of each group. Wet weight was calculated using the regression equation given previously in this section. Total biomass was computed as the sum of the biomasses of all size groups.

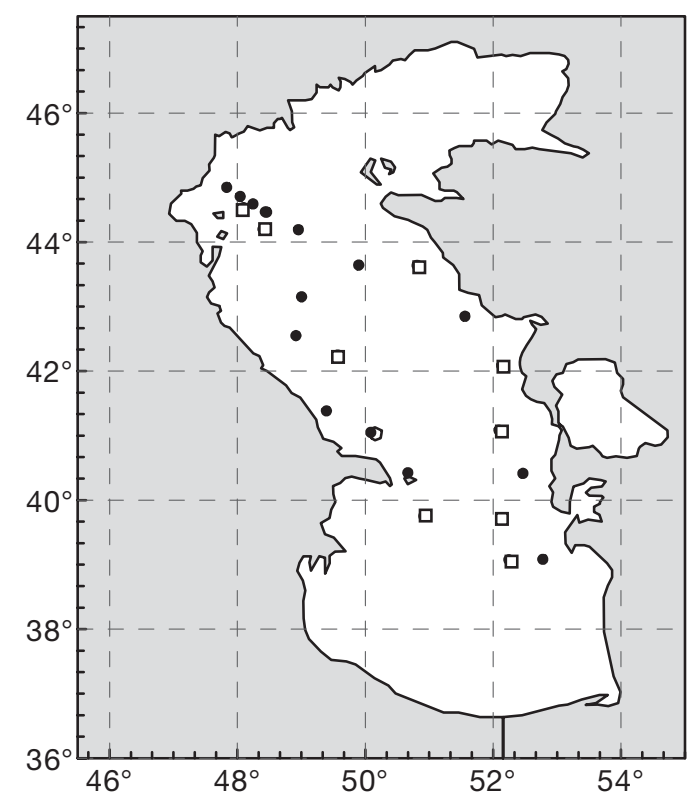

Fig. 1. Sampling stations in the Caspian Sea in August 2001 (ם, zooplankton and Mnemiopsis leidyi sampling; •, M. leidyi sampling only). The deepest stations were situated in the middle and southwestern areas, where depths varied from 35 to $735 \mathrm{~m}$. Salinity in the middle and southern Caspian varied from 12.6 to $13.0 \%$; temperature varied from 23.1 to $27.1^{\circ} \mathrm{C}$ in the eastern part and from 23.0 to $27.5^{\circ} \mathrm{C}$ in the western part 
Table 1. Mnemiopsis leidyi. Proximate biochemical composition in the Caspian Sea. N: number of samples analyzed

\begin{tabular}{|lccc|}
\hline Component & $\begin{array}{c}\text { Wet weight } \\
\left(\mathrm{mg} \mathrm{g}^{-1}\right)( \pm \mathrm{SD})\end{array}$ & $\begin{array}{c}\text { Organic matter } \\
(\%)( \pm \mathrm{SD})\end{array}$ & $\mathrm{N}$ \\
\hline Organic matter & $1.31 \pm 0.29$ & - & 30 \\
Protein & $1.04 \pm 0.21$ & $79.6 \pm 2.0$ & 30 \\
Lipids & $0.14 \pm 0.06$ & $9.9 \pm 2.2$ & 30 \\
Carbohydrates & $0.09 \pm 0.02$ & $6.7 \pm 1.1$ & 30 \\
Amino acids & $0.05 \pm 0.01$ & $3.8 \pm 0.5$ & 30 \\
\hline
\end{tabular}

Estimation of the predation rate by the ctenophore population was based on Mnemiopsis leidyi abundance, individual weights of the ctenophores in the population and the clearance rate measured in the laboratory for animals of various weights. The correction factor $Q_{10}=2.2$ was used to compute the clearance rate at ambient temperature during the entire year (Winberg 1983).

The daily rations of the ctenophore population in energy units were calculated from the clearance rate and zooplankton biomass values, assuming $1 \mathrm{mg}$ of zoo-
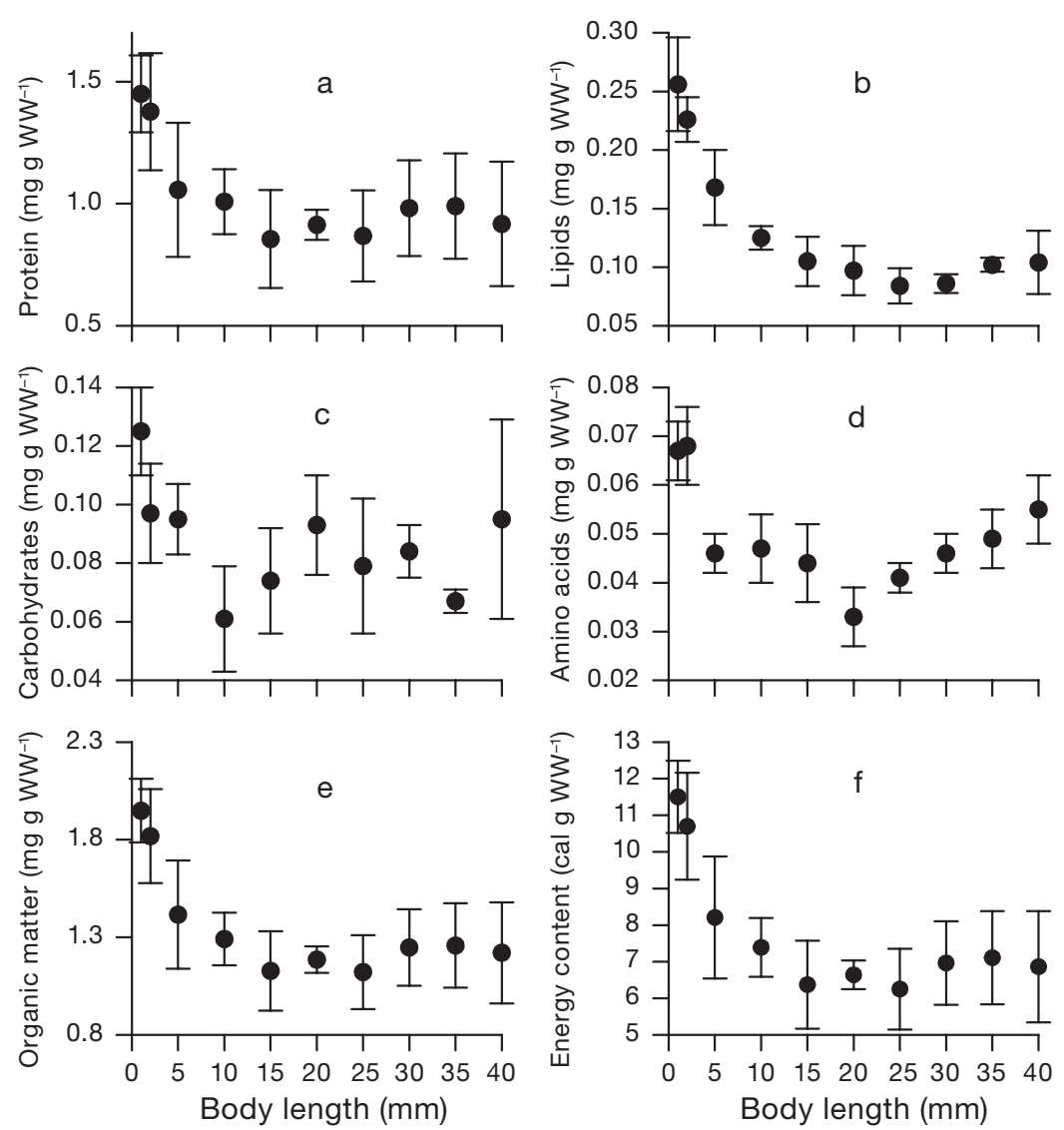

Fig. 2. Mnemiopsis leidyi. Proximate biochemical composition (per gram wet weight, WW): (a) protein, (b) lipids, (c) carbohydrates and (d) amino acids, as well as organic (e) and energy (f) contents in ctenophores of different sizes from the Caspian Sea (means $\pm \mathrm{SD}$ ) plankton wet weight to be equivalent to 1 cal (Vinogradova 1964). To estimate the population biomass of Mnemiopsis leidyi in energy units, the monthly average biomass (in wet weight) for each size group in the population was multiplied by size-specific caloric value of Mnemiopsis (see Fig. 2f). The daily minimum food requirements were computed by taking into account respiration rate measured in the laboratory and total numerical abundance of ctenophores from the field data.

\section{RESULTS}

\section{Chemical composition}

The organic matter content of Mnemiopsis leidyi in the Caspian Sea ranged from 0.1 to $0.2 \%$ WW. The predominant biochemical constituent of the whole body tissue of the ctenophore was protein (76 to $82 \%$ ), followed by lipids ( 7 to $13 \%$ ), carbohydrates (5 to $8 \%$ ) and free amino acids (3 to $5 \%$ ) (Table 1). Variability in specific organic content and its constituents was mainly due to the size spectrum of the individuals analyzed

(Fig. 2a-e). Over the whole size spectrum of ctenophores (1 to $40 \mathrm{~mm}$ ), all organic substances in $M$. leidyi changed per gram wet weight by approximately $1 / 2$. The components decreased especially sharply from 1 to $10-15 \mathrm{~mm}$ length specimens. In ctenophores with lengths of 10 to $40 \mathrm{~mm}$, the specific organic content remained relatively stable.

The energy content of Mnemiopsis leidyi also changed with body size, decreasing almost 2-fold with increasing individual length in the range from 1 to $15 \mathrm{~mm}$. Between 10 and $40 \mathrm{~mm}$, the value $($ mean $\pm \mathrm{SD})$ was $6.80 \pm 0.40 \mathrm{cal}$ $\mathrm{g}^{-1} \mathrm{WW}$.

\section{Feeding rate}

In our experiments, the clearance rate $( \pm \mathrm{SD})$ of this species (the volume that Mnemiopsis leidyi have to sweep in order to consume a specific number of prey items) ranged from $32.5 \pm 13.6$ to $112.2 \pm 59.0 \mathrm{ml}$ ind. ${ }^{-1} \mathrm{~h}^{-1}$ when consuming adults and copepodites of Acartia sp.; the rate increased with increasing predator weight (Fig. 3). The relationship between the clearance rate $(\mathrm{CR}, \mathrm{ml}$ ind $^{-1} \mathrm{~h}^{-1}$ ) and $M$. leidyi wet weight ( $\mathrm{g}$ ) can best be described by the following 


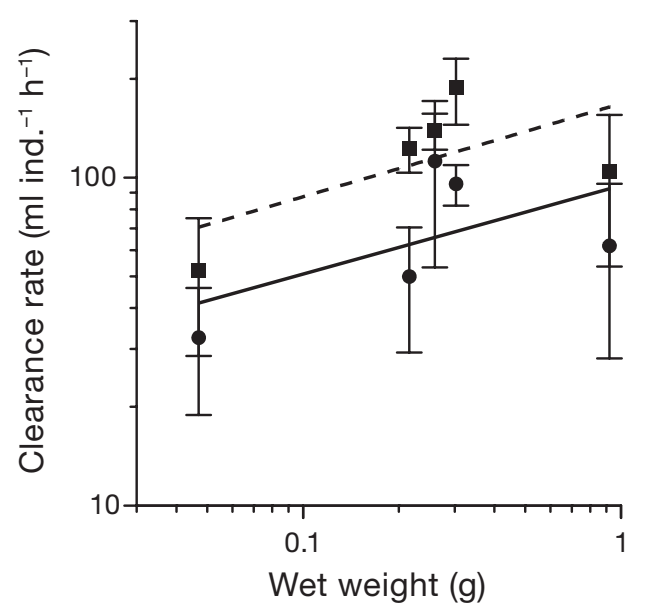

Fig. 3. Mnemiopsis leidyi. Relationship between clearance rate and wet weight (means $\pm \mathrm{SD}$ ). Ctenophores were fed Acartia sp. copepodites and adults (๑) or nauplii (

power function (Kremer 1976, Finenko \& Romanova 2000), which displays a higher coefficient of determination compared to the linear function (Båmstedt et al. 2000):

$$
\mathrm{CR}_{\mathrm{A}}=94.55 W^{0.270} \quad \mathrm{r}^{2}=0.670
$$

The clearance rate of ctenophores was about 2-fold higher when they fed on copepod nauplii:

$$
\mathrm{CR}_{\mathrm{n}}=168.08 W^{0.284} \quad \mathrm{r}^{2}=0.397
$$

The clearance rates on copepodites/adults and nauplii of Acartia sp. in terms of per unit wet weight were 2.27 and $4.03 \mathrm{l} \mathrm{g}^{-1}$ ctenophore WW d $\mathrm{d}^{-1}$. By using the wet weight $(W, \mathrm{~g})$ and volume $(V, \mathrm{ml})$ equation of Kideys \& Romanova (2001), $W=-0.249+V \times 0.886$, these values corresponded to 2.49 and $4.45 \mathrm{l} \mathrm{ml}^{-1}$ ctenophore $\mathrm{d}^{-1}$, in terms of per unit volume of ctenophore (for comparative purposes with the literature).

Power coefficients of these 2 equations (0.270 and 0.284) were close to each other. Since we did not have data on zooplankton composition, Eq. (1) (with the higher correlation value) was used to calculate the population clearance rate and estimate the predatory pressure of Mnemiopsis leidyi on mesozooplankton.

The weight-specific daily rations in the tested weight range of Mnemiopsis leidyi changed from 0.31 to $1.0 \%$ WW when they were fed on Acartia copepodites and adults at concentrations of 0.8 to $2.1 \mathrm{mg}$ $\mathrm{l}^{-1}$, but were only 0.08 to $0.33 \% \mathrm{WW}$ at low nauplii concentrations of 0.07 to $0.45 \mathrm{mg} \mathrm{l}^{-1}$. In terms of energy units, the difference between the 2 groups were even more notable: 32.7 to $122.3 \%$ in the group fed Acartia copepodites and adults and 9.9 to $38.6 \%$ of the body energy content in the nauplii-fed group (Table 2).

\section{Respiration rate}

The relationship between the oxygen consumption rate $\left(Q_{1} \mathrm{ml} \mathrm{O}_{2}\right.$ ind $\left.^{-1} \mathrm{~h}^{-1}\right)$ and the wet weight of Mnemiopsis leidyi (g) at $24^{\circ} \mathrm{C}$ (Fig. 4) is expressed by the equation:

$$
Q=0.0042 W^{0.776} \quad r^{2}=0.952
$$

The specific respiration rates of Mnemiopsis leidyi were weight dependent and decreased with increasing weight. Metabolic demands for ctenophores expressed as a percentage of body energy content ranged from 35 to $4 \%$ in the weight range from 0.001 to $10 \mathrm{~g} \mathrm{WW}$.

\section{Reproduction}

Mnemiopsis leidyi started to produce eggs in the Caspian Sea when it reached about $15 \mathrm{~mm}$ in total length, although in rare cases eggs were obtained from smaller ctenophores, even from a specimen of $12 \mathrm{~mm}$ length and $0.5 \mathrm{~g} \mathrm{WW}$.

There was a tendency for fecundity to increase with ctenophore size, though the most abundant size of reproducing Mnemiopsis leidyi was 20 to $30 \mathrm{~mm}$ in the Caspian Sea. The relationship between egg number in

\begin{tabular}{|c|c|c|c|c|c|c|}
\hline \multirow{3}{*}{$\begin{array}{c}\text { M. leidyi } \\
\text { wet weight } \\
\text { (g) }\end{array}$} & \multicolumn{3}{|c|}{ Copepodites and adults } & \multirow{3}{*}{$\begin{array}{c}\text { Food } \\
\text { concentration } \\
\left(\mathrm{mg} \mathrm{l}^{-1}\right)\end{array}$} & \multicolumn{2}{|c|}{ Nauplii } \\
\hline & \multirow{2}{*}{$\begin{array}{c}\text { Food } \\
\text { concentration } \\
\left(\mathrm{mg} \mathrm{l}^{-1}\right)\end{array}$} & \multicolumn{2}{|c|}{ Specific daily ration } & & \multicolumn{2}{|c|}{ Specific daily ration } \\
\hline & & $(\% \mathrm{WW})$ & (\% cal) & & $(\% \mathrm{WW})$ & (\% cal) \\
\hline $0.303 \pm 0.053$ & $2.0 \pm 0.5$ & $1.04 \pm 0.30$ & $122.3 \pm 31.9$ & $0.08 \pm 0.02$ & $0.08 \pm 0.02$ & $9.9 \pm 2.8$ \\
\hline $0.216 \pm 0.018$ & $2.1 \pm 0.4$ & $0.36 \pm 0.12$ & $42.5 \pm 12.9$ & $0.32 \pm 0.04$ & $0.33 \pm 0.01$ & $38.6 \pm 1.4$ \\
\hline $0.920 \pm 0.345$ & $1.0 \pm 0.2$ & $0.31 \pm 0.17$ & $32.7 \pm 29.1$ & $0.45 \pm 0.1$ & $0.09 \pm 0.04$ & $11.1 \pm 5.1$ \\
\hline
\end{tabular}

Table 2. Mnemiopsis leidyi. Daily rations of ctenophores feeding on different stages of Acartia sp. Means \pm SD were calculated from 4 measurements 


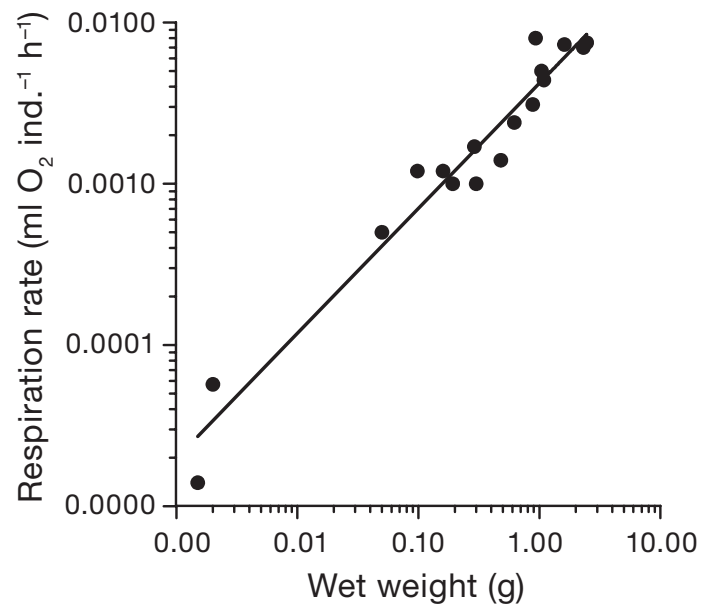

Fig. 4. Mnemiopsis leidyi. Relationship between respiration rate and wet weight at $24^{\circ} \mathrm{C}$

a clutch $(E)$ and $M$. leidyi length $(L, \mathrm{~mm})$ could be expressed by the power function: $E=1.77 \times L^{1.96}$ $\left(r^{2}=0.46\right.$; Fig. 5). The average fecundity of M. leidyi in the Caspian Sea was $906 \pm 470$ eggs (mean \pm SD) for freshly collected ctenophores from the examined length range.

\section{Population dynamics and the predatory impact of Mnemiopsis leidyi on the zooplankton community}

In the shallow waters of the southern Caspian, the abundance and biomass values of ctenophores were low (18 to 100 ind. $\mathrm{m}^{-2}$ and 0.8 to $4.5 \mathrm{~g} \mathrm{~m}^{-2}$ ) during the winter and early spring (January to April), gradually increasing during summer and autumn; maximum

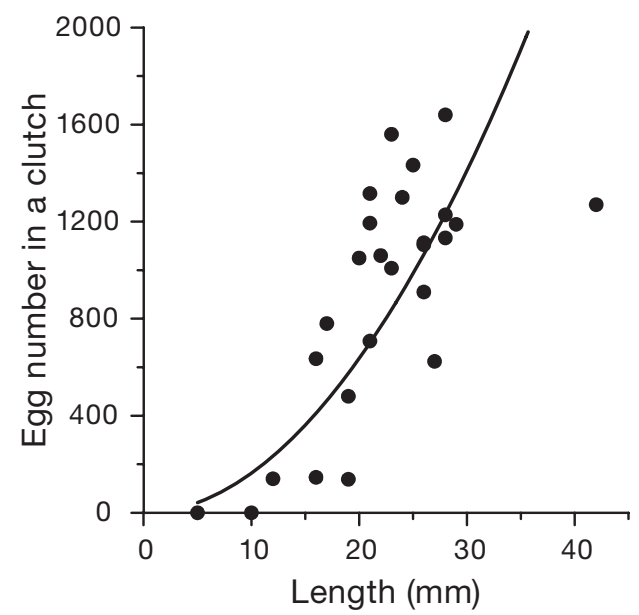

Fig. 5. Mnemiopsis leidyi. Effect of body length on egg number in a clutch in ctenophores from the Caspian Sea abundances and biomasses were observed from August to October (Fig. 6a,b). Reproduction mainly occurred in the warmer period, reaching its maximum in July or August. Minimum mean weight of specimens (which could be due to either spawning or probably shrinking) in the population was observed in March (Fig. 6c). However, there was a notable biomass increase after this period. Somatic growth appeared to take place from July to August/September and from October to December (Fig. 6c), when maximum weights of specimens were recorded. The mean
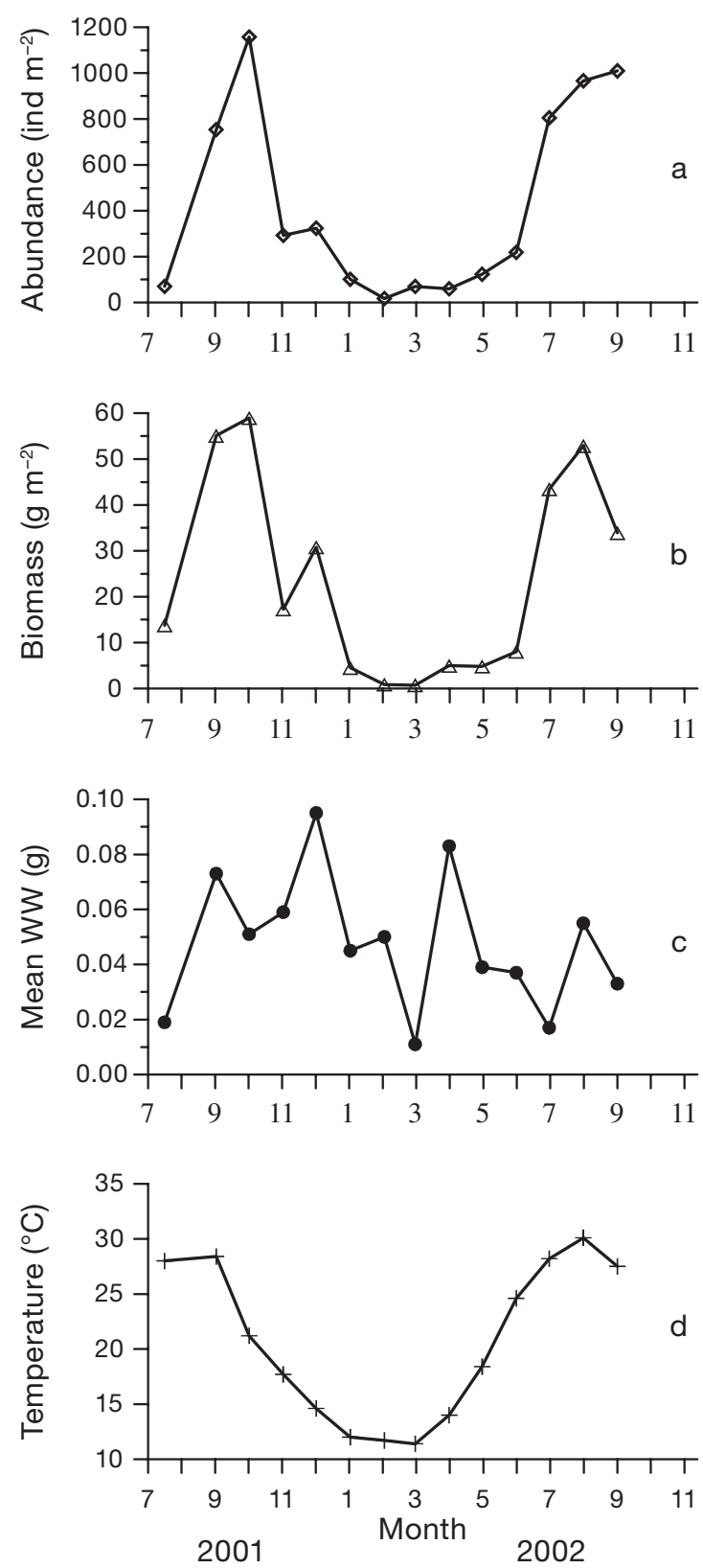

Fig. 6. Mnemiopsis leidyi. (a) Abundance, (b) biomass, (c) mean wet weight and (d) water temperature in southern Caspian waters in 2001 and 2002 
weights of specimens from March to April increased almost 8-fold. If ctenophore growth took place at a constant relative rate and was exponentially related to time (Reeve \& Walter 1978), the specific daily growth rate was 0.07 at temperatures between 11 and $14^{\circ} \mathrm{C}$. After this intensive growth period, ctenophores began reproduction that was maintained until July. So periods of somatic growth alternate with propagation periods in M. leidyi population dynamics in the southern Caspian Sea.

The largest size that the ctenophore could attain in the Caspian Sea was $65 \mathrm{~mm}$. However, it is striking to see that the year round population was mostly composed of small individuals, with an average weight of 0.011 to $0.095 \mathrm{~g}$ and an average length of 2 to $7 \mathrm{~mm}$. This size composition resulted in the very high predatory impact of the Mnemiopsis leidyi population on zooplankton, exceeding $100 \%$ of the daily zooplankton biomass in the summer/autumn months, when the maximum development of the ctenophore population occurred (Fig. 7). In winter and spring, the predatory effect decreased due to the decline in ctenophore abundance, but it still remained high (29 to $12 \%$ daily) (Table 3).

Minimum food requirements (or maintenance rations) were calculated as the respiration rates of the Mnemiopsis leidyi population. These were as high as $16 \%$ of the population biomass in summer at temperatures of 27 to $30^{\circ} \mathrm{C}$ and decreased to $4.6 \%$ in the winter months (Table 3). So, to grow in the summer months, M. leidyi must consume daily rations of $16 \%$ of its own biomass.

As for the spatial ctenophore distribution in summer (August 2001), minimum abundance was observed in the northern Caspian, but biomass was high, due to the large sizes of Mnemiopsis leidyi in that area (Fig. 1, Table 4). Probably, reproduction in that population had not yet started, in contrast to the populations in the

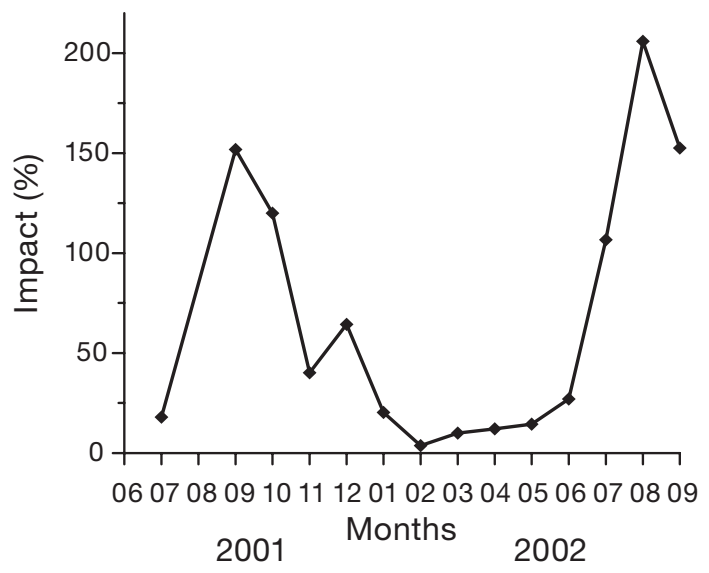

Fig. 7. Mnemiopsis leidyi. Predatory impact of the population on mesozooplankton in the southern Caspian Sea in 2001 and 2002 middle and southern Caspian, where maximum abundance but low biomass occurred. The mean individual weight of specimens in the middle and southern populations was 1 order of magnitude lower than that in the north. In the middle eastern and western Caspian, the individual weight of ctenophores was almost the same, but abundance and biomass were 1.5 times higher in the middle western.

The predatory impact of the Mnemiopsis leidyi population was as high as $62 \%$ of the total mesozooplankton biomass daily in the middle western and southern Caspian; however, this effect was only half as strong in the northern and middle eastern Caspian (Table 4). Food provision of the M. leidyi population was better in the middle eastern and southern Caspian (compared to the other regions), where the minimum specific food requirements of the population $(Q / B, \%)$ were close to the population daily rations $(R / B, \%)$, while in northern and western areas they were much higher than the rations.

\section{DISCUSSION}

\section{Chemical composition}

The proximate biochemical composition of the ctenophore Mnemiopsis leidyi was studied earlier for the Black Sea (Anninsky 1994) and for the Caspian Sea populations (Yousefian \& Kideys 2003). According to the Black Sea data, the organic matter content $($ mean $\pm \mathrm{SD})$ for this species was $1.15 \pm 0.15 \mathrm{mg} \mathrm{g}^{-1}$ WW and ranged from 0.98 to $1.55 \mathrm{mg} \mathrm{g}^{-1}$ within the ctenophore size spectrum from 3 to $68 \mathrm{~mm}$. Within a similar size range (3 to $40 \mathrm{~mm}$ ), an organic matter content of the Black Sea population was obtained of $1.12 \pm$ $0.16 \mathrm{mg} \mathrm{g}^{-1} \mathrm{WW}$ and did not differ $(\mathrm{p}>0.05)$ from the values for the Caspian Sea population $(1.18 \pm 0.19 \mathrm{mg}$ $\mathrm{g}^{-1} \mathrm{WW}$ ). In Yousefian \& Kideys' (2003) study for 10 to $20 \mathrm{~mm}$ ctenophores from the Caspian Sea, a very similar organic matter content was determined $(1.09 \mathrm{mg}$ $\left.\mathrm{g}^{-1} \mathrm{WW}\right)$. Thus, despite both different conditions in the seas (salinity, food availability, etc.) and different size spectra of M. leidyi in the Black and the Caspian Seas, there are no strong biochemical differences between these ctenophores.

It is of interest to compare these data with the results of carbon, hydrogen and nitrogen ( $\mathrm{CHN}$ ) analyses of ctenophore tissues from Biscayne Bay (Florida, USA). The carbon content expressed as a percentage dry weight (DW) in Mnemiopsis leidyi from this region changed between 1 and $13 \%$ in the size range of 1 to $>40 \mathrm{~mm}$ (Reeve et al. 1989). If we assume ctenophore dry weight to be nearly $3.4 \%$ of wet weight at the typical oceanic salinity $(34 \%$ ) (Kremer 
Table 3. Mnemiopsis leidyi. Population predation rate on zooplankton in shallow Iranian waters during different seasons from 2001 to 2002. Data are means \pm SD

\begin{tabular}{|lcccc|}
\hline Season & $\begin{array}{c}\text { Temp. } \\
\left({ }^{\circ} \mathrm{C}\right)\end{array}$ & $\begin{array}{c}\text { M. leidyi } \\
\text { biomass } \\
\left(\mathrm{g} \mathrm{m}^{-3}\right)\end{array}$ & $\begin{array}{c}\text { Percentage of } \\
\text { zooplankton biomass } \\
\text { consumed daily }\end{array}$ & $\begin{array}{c}\text { Daily maintenance } \\
\text { ration }(\%, M . \text { leidyi } \\
\text { biomass })\end{array}$ \\
\hline Autumn (Sep-Nov 2001) & $22.5 \pm 5.5$ & $43.76 \pm 23.05$ & $103.9 \pm 57.5$ & $10.1 \pm 4.3$ \\
Winter (Dec 2001-Feb 2002) & $12.7 \pm 1.3$ & $12.08 \pm 16.33$ & $29.5 \pm 31.4$ & $4.6 \pm 0.3$ \\
Spring (Mar-May 2002) & $12.2 \pm 2.2$ & $3.52 \pm 2.39$ & $12.1 \pm 2.2$ & $5.8 \pm 1.5$ \\
Summer (Jun-Aug 2002) & $27.6 \pm 2.8$ & $24.79 \pm 24.48$ & $113.2 \pm 89.6$ & $16.1 \pm 3.4$ \\
\hline
\end{tabular}

\& Nixon 1976), M. leidyi carbon content would be in the range of 0.35 to $4.55 \mathrm{mg} \mathrm{g}^{-1} \mathrm{WW}$. This means that the organic matter content (carbon $\times 1.9$, Omori \& Ikeda 1984) for the Biscayne Bay population would be equal to $0.67-7.58 \mathrm{mg} \mathrm{g}^{-1} \mathrm{WW}$. So, for the body length range from 5 to $40 \mathrm{~mm}$, organic matter content ( 0.67 to $1.33 \mathrm{mg} \mathrm{g}^{-1}$ ) was very similar to that of the Caspian Sea population (1.07 to $1.37 \mathrm{mg} \mathrm{g}^{-1}$ ). At the same time, values for the smallest specimens (1 to $4 \mathrm{~mm}$ ) tend to be 3- to 4-fold higher in Biscayne Bay ( 1.60 to $\left.7.58 \mathrm{mg} \mathrm{g}^{-1}\right)$ than in the Caspian Sea (1.37 to $1.90 \mathrm{mg} \mathrm{g}^{-1}$ ). Because of the lack of material for each size group, the data could not be tested statistically. But, to some extent, the discrepancies could be due to the exceptionally delicate structure of the smallest specimens and a food supply effect on the organic content of the ctenophore. Even for similar-sized M. leidyi specimens, the organic content could vary by at least 2-fold, depending on an individual's nutritional state (Reeve et al. 1989). On the whole, the similarity in organic content for M. leidyi of the Caspian and the Black Seas and of Biscayne Bay indicated that the metabolic rates of these ctenophores are not substantially different under the same conditions.
The general trend of a decrease in specific organic content and its constituents with size is a common feature in ctenophore species (Kremer at al. 1986, Reeve et al. 1989, Anninsky 1994). This is due to the nonhomogeneous distribution of organic matter among the different tissues constituting the ctenophores' body bulk. Their body consists of regions of carbonrich structures, such as ctenes, tentacles, muscles and gut wall, that are embedded in a very low carbon matrix (Reeve et al. 1989). The decrease observed in specific organic content with increasing Mnemiopsis leidyi size indicates that the ratio of low carbon matrix to wet weight increases gradually during somatic growth of the ctenophore. In fact, organic growth of $M$. leidyi occurs more slowly than it appears from the ctenophore wet weight increase.

\section{Respiration, reproduction and feeding}

The respiration rate of Caspian Sea Mnemiopsis leidyi is 1.5-fold higher than that of the Black Sea population (Anninsky \& Abolmasova 2000, Finenko \& Romanova 2000, Abolmasova 2001), which is probably a result of different food conditions (biomass of zoo-

Table 4. Mnemiopsis leidyi. Abundance, biomass, predatory impact, respiration and feeding rates of population in different regions of the Caspian Sea in August 2001 (Temp.: surface temperature; n: number of stations; $N$ : abundance; B: biomass; $W$ : mean wet weight of $M$. leidyi in the population; ZB: zooplankton biomass; PI: predatory impact; Q: respiration rate; $R$ : daily ration). Values are mean $\pm \mathrm{SE}$

\begin{tabular}{|lcccccccccccc}
\hline Region & $\begin{array}{c}\text { Temp. } \\
\left({ }^{\circ} \mathrm{C}\right)\end{array}$ & $\begin{array}{c}\text { Depth } \\
(\mathrm{m})\end{array}$ & $\mathrm{n}$ & $\begin{array}{c}N \\
\left(\mathrm{ind} . \mathrm{m}^{-3}\right)\end{array}$ & $\begin{array}{c}B \\
\left(\mathrm{~g} \mathrm{~m}^{-3}\right)\end{array}$ & $\begin{array}{c}W \\
(\mathrm{~g})\end{array}$ & $\begin{array}{c}\mathrm{ZB} \\
\left(\mathrm{g} \mathrm{m}^{-3}\right)\end{array}$ & $\begin{array}{c}\mathrm{PI} \\
(\%)\end{array}$ & $\begin{array}{c}Q \\
\left(\mathrm{cal} \mathrm{d}^{-1)}\right.\end{array}$ & $\begin{array}{c}R \\
\left(\mathrm{cal} \mathrm{d}^{-1}\right)\end{array}$ & $\begin{array}{c}Q / B \\
(\%)\end{array}$ & $\begin{array}{c}R / B \\
(\%)\end{array}$ \\
\hline $\begin{array}{c}\text { Northern } \\
\text { Caspian }\end{array}$ & $26.9 \pm 0.6$ & $5-24$ & 7 & $106.1 \pm 38.7$ & $42.9 \pm 10.1$ & $0.592 \pm 0.150$ & 31.95 & $28.1 \pm 8.2$ & $25.3 \pm 6.0$ & $9.0 \pm 2.6$ & $4.9 \pm 1.3$ & $1.9 \pm 0.6$ \\
$\begin{array}{c}\text { Eastern } \\
\text { middle }\end{array}$ & $25.3 \pm 0.50$ & $35-89$ & 6 & $221.8 \pm 89.6$ & $10.7 \pm 4.1$ & $0.182 \pm 0.094$ & 27.50 & $31.1 \pm 15.7$ & $10.1 \pm 4.2$ & $9.9 \pm 5.0$ & $3.5 \pm 1.5$ & $3.7 \pm 1.9$ \\
$\begin{array}{c}\text { Western } \\
\text { middle }\end{array}$ & $25.1 \pm 0.5$ & $35-725$ & 6 & $364.4 \pm 93.1$ & $45.7 \pm 13.4$ & $0.187 \pm 0.079$ & 27.50 & $61.5 \pm 15.1$ & $34.0 \pm 8.3$ & $19.6 \pm 4.8$ & $8.9 \pm 2.1$ & $5.8 \pm 1.6$ \\
$\begin{array}{c}\text { Southern } \\
\text { middle }\end{array}$ & $26.4 \pm 0.4$ & $35-735$ & 4 & $389.7 \pm 67.4$ & $21.0 \pm 2.0$ & $0.056 \pm 0.005$ & 31.73 & $61.9 \pm 10.2$ & $20.4 \pm 2.2$ & $19.8 \pm 3.2$ & $7.0 \pm 1.8$ & $6.8 \pm 1.3$ \\
\hline
\end{tabular}


plankton) and nutritional states of the ctenophores. A marked effect of food availability on the respiration rate of ctenophores has been shown (Kremer 1982, Finenko et al. 1995, Anninsky et al. 1998); the respiration rate of $M$. leidyi can change by a factor of 2, from low to high food concentration.

Mean fecundity of Mnemiopsis leidyi is lower in the Caspian Sea than in the Black Sea (906 \pm 470 compared to $3350 \pm 1385$ eggs in a clutch, respectively, with a maximum of about 6200 eggs ind. ${ }^{-1} \mathrm{~d}^{-1}$; T. Shiganova unpubl. data). The maximal size of $M$. leidyi in the Caspian Sea (45 mm in Kideys \& Moghim 2003, $65 \mathrm{~mm}$ in the present study) is also smaller than that recorded for the Black Sea, where this ctenophore could attain a length of $180 \mathrm{~mm}$ (Shiganova 1997).

A characteristic feature of the size composition of the Mnemiopsis leidyi population in shallow waters in the Caspian Sea (especially in the south) is the predominance of small ctenophores of $<10 \mathrm{~mm}$, similar to the results of Kideys \& Moghim (2003). These small ctenophores made up $86 \%$ of the total abundance in August 2001. The low salinity of the Caspian Sea might be the reason for the smaller size of ctenophores, as well as their low fecundity.

The aim of feeding experiments was to calculate the Mnemiopsis leidyi clearance rate in order to estimate its impact on the zooplankton community in different regions of the Caspian Sea. It is known that one of the most important characteristics of lobate ctenophores is the proportionality between the consumption rate and food concentration over an extremely wide range of prey concentrations (Bishop 1968, Reeve et al. 1978, Gibbson \& Painting 1992). In this case, the clearance rate does not depend on the prey density (Frost 1975, Kremer 1976, Monteleone \& Duguay 1988, Finenko \& Romanova 2000). In our feeding experiments of $6 \mathrm{~h}$ duration, the difference between initial and final concentrations was about $45 \%$, but, in accordance with the above conclusion, the clearance rate was not affected by lowered food concentrations. In the range of food concentrations from 0.7 to $2.1 \mathrm{mg} \mathrm{l}^{-1}$, the clearance rate was affected slightly by ctenophore weight and prey items: it was nearly twice as high on copepod nauplii as on copepodites and adults of Acartia sp. This difference was probably determined by the 2 different mechanisms of prey encounter demonstrated by $M$. leidyi, which function simultaneously. $M$. leidyi utilize 3 preycatching mechanisms during the course of development from larvae to adult stages (Sullivan \& Gifford 2004). From hatching until they reach $\sim 4 \mathrm{~mm}$ in length, they feed using their tentacles trailing passively. At a body length of $\sim 5 \mathrm{~mm}, \mathrm{M}$. leidyi larvae begin to develop small oral lobes and feed using a combination of tentaculate and lobate mechanisms to capture prey. At $\sim 6 \mathrm{~mm}, M$. leidyi larvae are exclusively lobate and use the same prey-capture mechanism as adults, which allows predation on both macrozooplankton using primarily the oral lobes and on microzooplankton using the tentacles (Costello \& Coverdale 1998, Waggett \& Costello 1999). Using these 2 different mechanisms of prey encounter allows ctenophores to obtain food from 2 nutrition sources (meso- and microzooplankton).

The main factors affecting the ctenophore clearance rates are temperature, body weight and prey item. In the experiments, container size and probably consumer density or the ratio between resource and consumer abundances also seemed to be important factors (Hansson et al. 2001); many authors have noted that feeding of ctenophores in the laboratory is depressed in small-sized containers. Hence, when the laboratory measurements are compared to the field results, the consumption rate seems to be underestimated. However, it is important to evaluate the magnitude of this underestimation. The grazing rates of Pleurobrachia pileus were measured from the stomach content of ctenophores kept in containers of $1300 \mathrm{~m}^{3}$, and in controlled laboratory experiments in smaller containers adopting a wide range of ctenophore sizes and food concentrations. Comparison of these values revealed that, in spite of large variability, both methods resulted in a mean difference factor of 2 (Sullivan \& Reeve 1982). The clearance rate of medium-sized Mnemiopsis leidyi in water volumes of 2001 increased by a factor of 3, as compared with 4 and 351 containers (Gibbson \& Painting 1992). So our calculations on $M$. leidyi consumption of the mesozooplankton community do not seem to be overestimated.

The estimated clearance rate for Caspian Mnemiopsis leidyi (2.49 to $4.45 \mathrm{l} \mathrm{ml}^{-1}$ of ctenophore $\mathrm{d}^{-1}$ ) feeding on copepods at similar temperatures is at the higher end of the range reported for this species from different regions of native waters $\left(4.21 \mathrm{ml}^{-1}\right.$ of ctenophore $\mathrm{d}^{-1}$ [Miller 1970] and 1.9 to $5.6 \mathrm{l} \mathrm{ml}^{-1}$ of ctenophore $\mathrm{d}^{-1}$ [Quaglietta 1987]; 0.9 to $3.01 \mathrm{ml}^{-1}$ of ctenophore $\mathrm{d}^{-1}$ [Kremer 1979] and 1.4 to $3.8 \mathrm{l} \mathrm{ml}^{-1}$ of ctenophore $\mathrm{d}^{-1}$ from the Black Sea [Finenko \& Romanova 2000]). In a recent study of effects of low dissolved oxygen on zooplankton predation by the ctenophore $M$. leidyi, the values of 1.2 to $2.64 \mathrm{l} \mathrm{ml}^{-1} \mathrm{~d}^{-1}$ were found in air-saturated conditions (Decker et al. 2004). Average per capita clearance rate for the 11 size classes of $M$. leidyi larvae and post-larvae $<10 \mathrm{~mm}$ feeding on assemblages of microplankton prey ranged from 0.216 to 5.51 ind..$^{-1} \mathrm{~d}^{-1}$ (Sullivan \& Gifford 2004). Unfortunately, no ctenophore volumes were mentioned in the cited paper, and we have not been able to calculate the volume-specific clearance rate. 


\section{Population dynamics and predatory impact}

There was a strong seasonality in the abundance of Mnemiopsis leidyi throughout the year (A. E. Kideys \& A. Roohi unpubl. data). Whilst up to 1200 specimens $\mathrm{m}^{-2}$ were present during the summer months, the population fell to very low levels of about 50 specimens $\mathrm{m}^{-2}$ during several months in the colder period. This means that there is what could be called mass mortality and, then, renewal of the population in the following summer. Similar phenomena have also been observed in the Black Sea (Finenko et al. 2003). So, the ctenophore population shrinks and expands again every year from small number of specimens. In this case, the genetic diversity of the species should become constrained by a bottleneck (depending on the few specimens that remain). This is, indeed, confirmed by substantial similarity in the genetics of $M$. leidyi (both from the nuclear and mitochondrial sequence data) collected from different regions of the world (Bayha \& Gaffney 2005).

Some previous studies showed an inverse correlation between the densities of crustaceans and gelatinous zooplankton, which led the authors to conclude that ctenophores control copepod biomass (Mountford 1980, Deason 1982, Vinogradov et al. 1992, Kovalev et al. 1998, Shiganova et al. 1998, Kideys et al. 2000, Hubareva et al. 2004). However, gelatinous predators ingesting $<10 \%$ of the zooplankton biomass daily cannot cause a substantial decrease in its abundance and biomass (Burrell \& Van Engel 1976, Kremer 1979, Larson 1987, Purcell \& Nemazie 1992, Purcell et al. 1994). Higher ingestion values ( $>20 \%$ ) will result in a sharp drop in prey abundance (Deason 1982, Matsakis \& Conover 1991, Purcell 1992). In its native waters of Chesapeake and Narragansett Bays, the maximum predation potential of the Mnemiopsis leidyi population could be as high as $31 \%$ of the total zooplankton biomass daily, with average values of 5 to $10 \%$ (Bishop 1968, Kremer 1979). The daily predation rate was about $20 \%$ of the zooplankton standing stock in Narragansett Bay when larvae and juveniles were taken into account, and up to $56-91 \%$ of the total grazing was due to predation by the $<1 \mathrm{~cm}$ size class of $M$. leidyi. Larval stages of $M$. leidyi had a disproportionate influence on predation relative to their biomass, because of their higher weight-specific clearance rate: it was 7 -fold lower in adults $\left(0.052 \mathrm{l} \mathrm{mg}^{-1} \mathrm{DW} \mathrm{d}^{-1}\right)$ compared to larval stages $\left(0.36 \mathrm{l} \mathrm{mg}^{-1} \mathrm{DW} \mathrm{d} \mathrm{d}^{-1}\right)$ at 20 to $25^{\circ} \mathrm{C}$ (Deason 1982, Kremer 1979).

In Sevastopol Bay (northern Black Sea) from July to August 1995 and in open waters of the Black Sea during September 1996, 6 to 7 yr after the main Mnemiopsis leidyi bloom, daily grazing values by this ctenophore were still as high as 30 to $40 \%$ of the zoo- plankton biomass (Anninsky et al. 1998, Finenko \& Romanova 2000). In August/September 2000 and August 2001, after appearance of the invasive predator Beroe ovata, the $M$. leidyi population could only remove daily 4 to $6 \%$ and about $16 \%$ of the zooplankton biomass, respectively. During other periods of the year, the grazing effect on zooplankton was very low $\left(<1 \% \mathrm{~d}^{-1}\right)$ due to the effectiveness of the top-down control of M. leidyi by B. ovata (Finenko et al. 2003, Kideys et al. 2004).

In the Caspian Sea, the effect of ctenophores on the zooplankton community during the first years of invasion was more destructive than in all other regions affected by Mnemiopsis leidyi. In the southern Caspian (i.e. Iranian waters), the effect was highest in summer, due to high water temperatures and to a population size structure in which juvenile ctenophores with mean lengths of 2 to $5 \mathrm{~mm}$ accounted for most of population. These ctenophores consumed the available stock of zooplankton during 3 to $8 \mathrm{~d}$ in the winter and spring months, but practically during $1 \mathrm{~d}$ in summer. In other regions (northern and middle Caspian), the M. leidyi pressure on the zooplankton community in August 2001 was also huge, and the food supply could be consumed in 1.5 to $3 \mathrm{~d}$. The great predatory impact of $M$. leidyi is supported by zooplankton abundance and biomass values, which decreased in the Caspian Sea after M. leidyi appeared. In the northern Caspian, zooplankton abundance dropped by a factor of 5.3 and biomass declined 6-fold in October 2000, as compared to July of that year. Most of this change occurred in the Copepoda. In the middle and southern Caspian, the annual values of zooplankton biomass dropped by factors of 4 (middle Caspian) and 9 (southern Caspian), in comparison to those from 1998. In 2001, the effect on the zooplankton became much more decisive, and it was paralleled by a huge increase in the population size of M. leidyi (Shiganova et al. 2004).

Our calculations of the ingestion rate (daily rations) of the Mnemiopsis leidyi population were based on clearance rates from laboratory experiments and mean in situ zooplankton concentrations. A comparison of these calculations with the measured metabolic requirements revealed that ctenophores did not have sufficient food to sustain growth in any of the regions. Only in the middle eastern and southern Caspian, where respiration and ingestion rates were similar and displayed a high assimilation efficiency $(0.8$; Reeve et al. 1978), could the population possibly meet its minimum food requirements. In other regions, for example, in the middle western and especially in the northern Caspian, the ctenophores lack food. Miller \& Williams (1972), interpreting published data for the Patuxent River Estuary, also showed that the zooplankton stock could only maintain the $M$. leidyi population for a very 
short period (in most cases $<1 \mathrm{~d}$ ), so the main outcome of their study was to pose the question as to what ctenophores eat in the sea. It should be mentioned, however, that a number of factors affect the feeding rates in situ, e.g. prey selection, different digestion times of prey items, prey behavior (especially swimming speed and direction), prey vulnerability (ability to escape) and relative prey availability (prey density and distribution) (Ivlev 1961, Reeve \& Walter 1978, Underwood et al. 2004). In situ prey densities are difficult or impossible to accurately measure when prey are patchy over small spatial scales. It appears that patches of Acartia sp. may reach densities up to 15 times greater than mean values (Larson 1987), and thus using mean zooplankton densities for ration calculations would result in distortions. However, no general principles exist yet to assess the effect of such factors, and their significance for ctenophores must still be determined.

It is of interest to compare the laboratory and in situ feeding rates, since laboratory-measured clearance rates have been extrapolated to field populations to predict predatory impact. In situ investigations of Mnemiopsis leidyi gut content, digestive time and ctenophore number were carried out by Larson (1987) in Link Port (Florida, USA) and by Zaika \& Revkov (1998) in the Black Sea. These studies showed that copepods (both nauplii and adults) were the most important prey items, along with cladocerans (in the Black Sea), barnacle nauplii and bivalve veligers. In Larson's study, clearance rates of $5 \mathrm{~cm} \mathrm{M}$. leidyi specimens ranged from 0.1 to 1.31 ind..$^{-1} \mathrm{~h}^{-1}$, depending on prey taxon. These values were lower than those from laboratory experiments, but the difference was not statistically significant. We calculated clearance rates from Zaika \& Revkov's (1998) data on M. leidyi gut content in the Black Sea in July 1992, by taking into account our data on digestion period (Finenko et al. 2005) and data on $M$. leidyi abundance during that time from Mutlu et al. (1994). The clearance rates of M. leidyi (190 g WW) varied from 2.08 to $9.171 \mathrm{ind}^{-1} \mathrm{~h}^{-1}$ for different prey items (bivalve veligers, cladoceran Pleopis polyphemoides and copepods) and amounted to $0.5-2.2 \mathrm{~g}^{-1} \mathrm{DW} \mathrm{h}{ }^{-1}$. These values were close to those obtained from laboratory experiments elsewhere (Kremer 1979, Miller 1970, Quaglietta 1987).

Predatory pressure of Mnemiopsis leidyi on Pleopis polyphemoides which was the main component of the zooplankton, varied from 8 to $63 \%$ (mean \pm SD: $32 \pm 26 \%$ ) of their stock in different regions. Based on these data, we consider that results of laboratory experiments can be used to extrapolate for field populations. The weakness of such an extrapolation is that prey preference is not taken into account; however, food selectivity in $M$. leidyi is questionable. According to our calculations based on Zaika \& Revkov's findings, consumption of different prey items was proportional to their relative densities in the total zooplankton abundance.

Prey food (Acartia tonsa and/or A. clausi) used in our study consisted of nearly the only mesozooplankton species surviving in coastal waters of the southern Caspian Sea, especially after the endemic cladoceran species disappeared (Kideys et al. 2005). So, at present, these copepod species, whether preferred or not, are the main food source for Mnemiopsis leidyi. Thus, we are not sure if Acartia sp. is a preferred food of ctenophores; this quandary requires further and specially designed experiments (Underwood et al. 2004). Such studies would be very useful both for understanding why other mesozooplankton species (mainly cladocerans, but also some other copepod species) disappeared from the ecosystem and for better quantification of predation impact. Such an approach could also aid in explaining the decreased levels (and hence) impact of $M$. leidyi observed over the years, both in the Black Sea and the Caspian Sea. Similar trends in other cases of invasion tempt us to suggest that both impacted prey and competitors 'learn' (as suggested by Underwood et al. 2004), in this case, how to deal with the invasive species.

Besides zooplankton, Mnemiopsis leidyi probably has additional food sources. Stoecker et al. (1987) and Sullivan \& Gifford (2004) discovered that phytoplankton, planktonic ciliates and other species of microplankton could be an important component of the diet of $M$. leidyi, especially for larvae and post-larvae with lengths $<10 \mathrm{~mm}$. In our study $M$. leidyi of $<10 \mathrm{~mm}$ comprised 86 to $90 \%$ of the total ctenophore abundance during the periods of maximum ctenophore populations, i.e. 670 to 1040 ind. $\mathrm{m}^{-3}$ in September and October 2001 and 830 to 870 ind. $\mathrm{m}^{-3}$ in August and September 2002. To calculate the potential trophic impact of these small ctenophores on microzooplankton, we applied Sullivan \& Gifford's (2004) equation $(\mathrm{CR}=9.316 L+4.541$, where $\mathrm{CR}$ is clearance rate $[\mathrm{ml}$ ind..$^{-1} \mathrm{~h}^{-1}$ ] and $L$ is $M$. leidyi length [mm]) to our abundance data, supposing that the mean length of ctenophores is $5 \mathrm{~mm}$. Our calculations showed that M. leidyi larvae can potentially clear daily from 83 to $128 \%$ of the water column in September and October 2001 and from 102 to $107 \%$ in August and September 2002. Thus, predation on microplankton can be so significant that predation pressure on mesozooplankton decreases.

Our hypothesis is supported by the estimations of potential daily grazing of microzooplankton and daily rations of ctenophore populations in Sevastopol Bay (the Black Sea) in August 2003. The calculations revealed that the daily grazing of microzooplankton was 
as high as 23 to $25 \%$ of its biomass, and daily rations of Mnemiopsis leidy larvae on microzooplankton were close to those on mesozooplankton ( 0.7 to $29.3 \%$ and 0.7 to $13.1 \%$ of the energy content, respectively) (Finenko et al. in press). Possibly, using mesozooplankton and microplankton together as 2 food sources, the ctenophores were not only able to meet their metabolic requirements, but had excess energy for growth.

Assuming a daily body loss of $1 \%$ of body caloric value, the starvation period that caused the largest specimen (65 mm, or $19.2 \mathrm{~g}$ ) to shrink to $12 \mathrm{~mm}$ (or $0.37 \mathrm{~g}$, being the onset of adult size found in the present study) could also be calculated as 394 d (by using the exponential decrease equation: $0.37=19.2(1-0.001)^{n}$, where $n$ is the number of days (Krebs 1972) at winter temperatures of $12.7^{\circ} \mathrm{C}$ (see Table 3). However, gradually increasing temperature and decreasing body weights will greatly shorten this theoretical maximum starvation period. Finding occasional food items during these periods will, however, extend the starvation period. This must be the strategy employed by Mnemiopsis leidyi to overcome the low food availability period in colder months.

Our overall results indicate that the warnings of several investigators that 'the impact of Mnemiopsis leidyi on the Caspian Sea ecosystem could be much worse than in the Black Sea' appear to be true. Assuming that the daily consumption rate of the $M$. leidyi population does not exceed $10 \%$ of the zooplankton biomass and the mean clearance rate calculated from our feeding experiments is about 1.51 ind. ${ }^{-1} \mathrm{~d}^{-1}$, the computed critical ctenophore biomass that would not affect (decrease) the abundance of mesozooplankton in the Caspian Sea is about $4 \mathrm{~g} \mathrm{~m}^{-3}$, or $120 \mathrm{~g} \mathrm{~m}^{-2}$ if the majority of ctenophores occur in the upper $30 \mathrm{~m}$ layer (Kideys \& Moghim 2003). As is clear from the monitoring data, the M. leidyi biomass in summer in different regions of the Caspian Sea is far in excess of this value. Such a high pressure exerted by this ctenophore would not allow zooplankton biomass levels to rise, and, as a consequence, no recovery can be foreseen with respect to the catch of planktivorous pelagic fishes until M. leidyi levels decrease substantially.

Acknowledgements. This study was made possible by the organizational efforts of Dr. V. Vladymyrov and H. Ghaffarzadeh (Caspian Environment Program) under the financial support of UNOPS, Project RER98G32, and Drs. S. Rezvani and H. Negarestan of the Iranian Fisheries Research Organization (IFRO). We greatly appreciate the help of M. T. Rostamian, A. Salmani, S. H. Ghasemi, F. Parafkandeh, M. Najafpour, M. Nazaran, A. R. Kihansani, J. Sharifi, T. M. Pormand, A. Nasrollatabar, M. Ebrahimzadeh, A. Jafarei, M. Yousefian and R. Ahmedinejad during our experiments. We thank 2 anonymous reviewers for their valuable comments on the manuscript. This effort is a cooperation project of the Census of Marine Zooplankton (CMarZ), a field project of the Census of Marine Life.

\section{LITERATURE CITED}

Abolmasova GI (2001) Effect of temperature and food conditions on energy metabolism in Mnemiopsis leidyi. Hydrobiol J 37:90-96 (in Russian)

Amenta JS (1964) A rapid chemical method for quantification of lipids separated by thin-layer chromatography. J Lipid Res 5:270-273

Anninsky BE (1994) Chemical composition of different size individuals of three species of gelatinous macroplankton in the Black Sea. Biol Morya 20:390-395 (in Russian)

Anninsky BE, Abolmasova GI (2000) Temperature as a factor influencing the intensity of the metabolism and mass development of the ctenophore Mnemiopsis leidyi in the Black Sea. Oceanology 40:686-692

Anninsky BE, Romanova ZA, Abolmasova GI, Gücü AC, Kideys AE (1998) Ecological and physiological state of the ctenophore Mnemiopsis leidyi (Agassiz) in the Black Sea in autumn 1996. In: Ivanov L, Oguz T (eds) Ecosystem modeling as a management tool for the Black Sea. Symposium on scientific results, Vol 1. Kluwer Academic Publishers, Dordrecht, p 249-262

Baker LD, Reeve MR (1974) Laboratory culture of the lobate ctenophore Mnemiopsis mccradyi with notes on feeding and fecundity. Mar Biol 26:57-62

Båmstedt U, Gifford DJ, Irigoien X, Atkinson A, Roman M (2000) Expression of zooplankton feeding rates and common conversion factors. In: Harris RP, Wiebe PH, Lenz J, Skjoldal HR, Huntley M (eds) ICES zooplankton methodology manual. Academic Press, New York, p 297-399

Bayha KM, Gaffney PM (2005) Molecular systematics and phylogeography of the invasive ctenophore Mnemiopsis based on nuclear and mitochondrial markers. Abstract presented at the ASLO International Meeting, Santiago de Compostela, Spain, 19-24 June 2005. Available from http://aslo.org/meetings/santiago2005/abstracts/1842.htm

Bishop JW (1968) A comparative study of feeding rates of tentaculate ctenophores. Ecology 49:996-997

Burrell VG, Van Engel WA (1976) Predation by and distribution of a ctenophore, Mnemiopsis leidyi A. Agassiz, in the York River Estuary. Estuar Coast Mar Sci 4:235-242

Clarke A, Holmes LJ, Gore DJ (1992) Proximate and elemental composition of gelatinous zooplankton from the Southern Ocean. J Exp Mar Biol Ecol 155:55-68

Costello JH, Coverdale R (1998) Planktonic feeding and evolutionary significance of the lobate body plan within the ctenophora. Biol Bull (Woods Hole) 195:247-248

Deason EE (1982) Mnemiopsis leidyi (Ctenophora) in Narragansett Bay, 1975-1979: abundance, size composition and estimation of grazing. Estuar Coast Shelf Sci 15: 121-134

Decker MB, Breitburg DL, Purcell JE (2004) Effects of low dissolved oxygen on zooplankton predation by the ctenophore Mnemiopsis leidyi. Mar Ecol Prog Ser 280:163-172

Dubois M, Gilles KA, Hamilton JK, Rebers PA, Smith F (1956) Colorimetric method for determination of sugars and related substances. Anal Chem 28:350-356

Dumont HJ (1995) Ecocide in the Caspian. Nature 377:673-674

Finenko GA, Romanova ZA (2000) Population dynamics and energetics of ctenophore Mnemiopsis leidyi in Sevastopol Bay. Oceanology 40:677-685

Finenko GA, Abolmasova GI, Romanova ZA (1995) Consumption, respiration and growth rates of Mnemiopsis mccradyi in relation to food conditions. Biol Morya 21: 315-320 (in Russian)

Finenko GA, Romanova ZA, Abolmasova GI, Anninsky BE, Svetlichny LS, Hubareva ES, Bat L, Kideys AE (2003) 
Population dynamics, ingestion, growth and reproduction rates of the invader Beroe ovata and its impact on plankton community in Sevastopol Bay, the Black Sea. J Plankton Res 25:539-549

Finenko GA, Romanova ZA, Abolmasova GI, Anninsky BE, Gubareva ES, Bat L, Kideys A (2005) Effect of food conditions on ingestion rate and digestion time in lobate ctenophore Mnemiopsis leidyi. J Mar Ecol 4(1):75-83 (in Russian)

Finenko GA, Romanova ZA, Abolmasova GI, Anninsky BE, Pavlovskaya TV, Bat L, Kideys A (in press) Ctenophora invaders and their role in trophodynamics of the planktonic community in the coastal waters of the Crimea area of the Black Sea (Sevastopol Bay). Oceanologia (in Russian)

Folch J, Lees M, Sloane-Stanley GH (1957) A simple method for the isolation and purification of total lipids from animal tissues. J Biol Chem 226:251-262

Frost BW (1975) A threshold feeding behaviour in Calanus pacificus. Limnol Oceanogr 20:263-269

GESAMP (IMO/FAO/UNESCO-IOC/WMO/WHO/IAEA/UN/ UNEP Joint Group of Experts on the Scientific Aspects of Marine Environmental Protection) (1997) Opportunistic settlers and the problem of the ctenophore Mnemiopsis leidyi invasion in the Black Sea. Rep Stud GESAMP 58:1-84

Gibbson MJ, Painting SJ (1992) The effects and implications of container volume on clearance rates of the ambush entangling predator Pleurobrachia pileus (Ctenophora: Tentaculata). J Exp Mar Biol Ecol 163:199-208

Gifford DJ (1993) Consumption of Protozoa by copepods feeding on natural microzooplankton assemblages. In: Kemp PF, Sherr BF, Sherr EB, Cole JJ (eds) Handbook of methods in aquatic microbial ecology. Lewis Publishers, Boca Raton, FL, p 723-729

Hansson S, De Stasio BT, Gorokhova E, Mohammadian MA (2001) Ratio-dependent functional responses - tests with the zooplanktivore Mysis mixta. Mar Ecol Prog Ser 216: 181-189

Hartree EF (1972) Determination of protein: a modification of the Lowry method that gives a linear photometric response. Anal Biochem 48:422-427

Hubareva ES, Svetlichny LS, Romanova ZA, Abolmasova GI, Finenko GA, Bat L, Kideys A (2004) State of zooplankton community in the Sevastopol Bay after invasion of ctenophore Beroe ovata to the Black Sea (1999-2003). Mar Ecol J 3(1):39-46 (in Russian)

Ivanov PI, Kamakim AM, Ushivtzev VB, Shiganova TA and 5 others (2000) Invasion of Caspian Sea by the comb jellyfish Mnemiopsis leidyi (Ctenophora). Biol Invasions 2: $255-258$

Ivlev VS (1961) Experimental ecology of the feeding of fishes. Yale University Press, New Haven, CT

Kideys AE (1994) Recent dramatic changes in the Black Sea ecosystem: the reason for the sharp decline in Turkish anchovy fisheries. J Mar Syst 5:171-181

Kideys AE (2002) Fall and rise of the Black Sea ecosystem. Science 297(5586):1482-1484

Kideys AE, Romanova Z (2001) Distribution of gelatinous macrozooplankton in the southern Black Sea during 1996-1999. Mar Biol 139:535-547

Kideys AE, Moghim M (2003) Distribution of the alien ctenophore Mnemiopsis leidyi in the Caspian Sea in August 2001. Mar Biol 142:163-171

Kideys AE, Kovalev AV, Shulman G, Gordina A, Bingel F (2000) A review of zooplankton investigations of the Black Sea over the last decade. J Mar Syst 24:355-371

Kideys AE, Shahram G, Davood G, Roohi A, Bagheri S (2001a) Strategy for combating Mnemiopsis in the Caspian waters of Iran. Final report prepared for the Caspian Environment Programme, Baku, Azerbaijan

Kideys AE, Jafarov FM, Kuliyev Z, Zarbalieva T (2001b) Monitoring Mnemiopsis in the Caspian waters of Azerbaijan. Final report prepared for the Caspian Environment Programme, Baku, Azerbaijan

Kideys AE, Finenko G, Anninski B, Shiganova T and 6 others (2004) Physiological characteristics of the ctenophore Beroe ovata in the Caspian Sea water. Mar Ecol Prog Ser 266:111-121

Kideys AE, Roohi A, Bagheri S, Finenko G, Kamburska L (2005) Impacts of invasive ctenophores on the fisheries of the Black Sea and Caspian Sea. Oceanography (Black Sea Spec Issue) 18(2):76-85

Kiselev IA (1969) Plankton of seas and continental reservoirs. Nauka, Leningrad (in Russian)

Kovalev AV, Gubanova AD, Kideys AE, Melnikov VV and 6 others (1998) Long-term changes in the biomass and composition of fodder zooplankton in coastal regions of the Black Sea during the period 1957-1996. In: Ivanov LI, Oguz T (eds) Ecosystem modelling as a management tool for the Black Sea, Vol 1. Kluwer Academic Publishers, Dordrecht, p 209-219

Krebs CJ (1972) Ecology: the experimental analysis of distribution and abundance. Harper \& Row Publishers, New York

Kremer P (1976) Population dynamics and ecological energetics of a pulsed zooplankton predator, the ctenophore Mnemiopsis leidyi. Estuar Process 1:197-215

Kremer P (1979) Predation by the ctenophore Mnemiopsis leidyi in Narragansett Bay, Rhode Island. Estuaries 2:97-105

Kremer P (1982) Effect of food availability on the metabolism of the ctenophore Mnemiopsis mccradyi. Mar Biol 71: 149-156

Kremer P, Nixon SW (1976) The distribution and abundance of the ctenophore Mnemiopsis leidyi in Narragansett Bay. Estuar Coast Mar Sci 4:627-639

Kremer P, Kanino MF, Gilmer RF (1986) Metabolism of epipelagic tropical ctenophores. Mar Biol 90:403-412

Kuzmenko MI (1975) The determination of amine nitrogen by ninhydrine reagent of new composition. In: Sirenko LA (ed) Methods of physiological-biochemical investigation of algae in hydrobiological practice. Naukova Dumka, Kiev, p 116-118 (in Russian)

Larson RJ (1987) In situ feeding rates of the ctenophore Mnemiopsis mccradyi. Estuaries 10:87-91

Matsakis S, Conover RJ (1991) Abundance and feeding of medusae and their potential impact as predators on other zooplankton in Bedford Basin (Nova Scotia, Canada) during spring. Can J Fish Aquat Sci 48:1419-1430

Miller RJ (1970) Distribution and biomass of an estuarine population of the ctenophore, Mnemiopsis leidyi. $\mathrm{PhD}$ thesis, North Carolina State University, Raleigh

Miller RJ, Williams RB (1972) Energy requirements and food supplies of ctenophores and jellyfish in the Patuxent River Estuary. Chesapeake Sci 13:328-331

Monteleone DM, Duguay L (1988) Laboratory studies of predation by the ctenophore Mnemiopsis leidyi on the early stages in the life history of the bay anchovy, Anchoa mitchilli. J Plankton Res 10:359-372

Mountford K (1980) Occurrence and predation by Mnemiopsis leidyi in Barnegat Bay, New Jersey. Estuar Coast Mar Sci 10:393-402

Mutlu E (1999) Distribution and abundance of ctenophores, and their zooplankton food in the Black Sea. II. Mnemiopsis leidyi. Mar Biol 135:603-613

Mutlu E, Bingel F, Gücü AC, Melnikov VV, Niermann U, Ostrovskaya NA, Zaika VE (1994) Distribution of the new 
invader Mnemiopsis sp. and the resident Aurelia aurita and Pleurobrachia pileus populations in the Black Sea in the years 1991-1993. ICES J Mar Sci 51:407-421

Omori MS, Ikeda T (1984) Methods in marine zooplankton ecology. John Wiley and Sons, New York

Petipa TS (1957) On average weight of the main zooplankton forms in the Black Sea. Proceedings of Sevastopol Biological Station 9, Sevastopol:39-57 (in Russian)

Pianka HD (1974) Ctenophora. In: Giese AC, Pearse JS (eds) Reproduction of marine invertebrates, Vol 1. Academic Press, New York, p 201-265

Purcell JE (1992) Effects of predation by the scyphomedusan Chrysaora quinquecirrha on zooplankton populations in Chesapeake Bay. Mar Ecol Prog Ser 87:65-76

Purcell JE, Nemazie DA (1992) Quantitative feeding ecology of the hydromedusan Nemopsis bachei in Chesapeake Bay. Mar Biol 113:305-311

Purcell JE, White JR, Roman MR (1994) Predation by gelatinous zooplankton and resource limitation as potential controls on Acartia tonsa copepod populations in Chesapeake Bay. Limnol Oceanogr 39:263-278

Quaglietta CE (1987) Predation by Mnemiopsis leidyi on hard clam larvae and other natural zooplankton in Great South Bay, NY. MSc thesis, 1987, New York State University, Stony Brook, NY

Reeve MR, Walter MA (1978) Nutrition ecology of ctenophores - a review of recent research. Adv Mar Biol 15: 249-287

Reeve MR, Walter MA, Ikeda T (1978) Laboratory studies of ingestion and food utilization in lobate and tentaculate ctenophores. Limnol Oceanogr 23:740-750

Reeve MR, Syms MA, Kremer P (1989) Growth dynamics of a ctenophore (Mnemiopsis) in relation to variable food supply. I. Carbon biomass, feeding, egg production, growth and assimilation efficiency. J Plankton Res 11: $535-552$

Sergeeva NG, Zaika VE, Mikhailova TV (1990) Nutrition of ctenophora Mnemiopsis mccradyi under conditions of the Black Sea. Ecol Morya 35:16-22 (in Russian)

Shiganova TA (1997) Mnemiopsis leidyi abundance in the Black Sea and its impact on the pelagic community. In: Ozsoy E, Mikaelyan A (eds) Sensitivity of North Sea, Baltic Sea and Black Sea to anthropogenic and climatic changes. Kluwer Academic Publishers, Dordrecht, p 117-130

Shiganova TA, Niermann U, Gücü AC, Kideys A, Khoroshilov VS (1998) Changes of species diversity and their abundance in the main components of pelagic community after Mnemiopsis leidyi invasion. In: Ivanov LI, Oguz T (eds) Ecosystem modelling as a management tool for the Black Sea, Vol 1. Kluwer Academic Publishers, Dordrecht, p 171-188

Shiganova TA, Kamakin AM, Zhukova OP, Ushivtzev VB, Dulimov B, Musayeva EI (2001) The invader into the

Editorial responsibility: Otto Kinne (Editor-in-Chief), Oldendorf/Luhe, Germany
Caspian Sea ctenophore Mnemiopsis and its initial effect on the pelagic ecosystem. Oceanology 41:517-524

Shiganova TA, Sapognikov VV, Musaeva EI, Domanov MM, Bulgakova YV (2003) Factors that determine pattern of distribution and abundance Mnemiopsis leidyi in the northern Caspian. Oceanology 43:716-733

Shiganova TA, Dumont HJ, Sokolsky AF, Kamakin AM, Tinenkova D, Kurasheva EK (2004) Population dynamics of Mnemiopsis leidyi in the Caspian Sea, and effects on the Caspian ecosystem. In: Dumont H, Shiganova TA, Nierman $\mathrm{U}$ (eds) Aquatic invasions in the Black, Caspian, and Mediterranean Seas. NATO ASI Ser 4 Earth Environ Sci 35: 71-113

Stanlow KA, Reeve MR, Walter MA (1981) Growth, food, and vulnerability to damage of the ctenophore Mnemiopsis mccradyi in its early life history stages. Limnol Oceanogr 26:224-234

Stoecker DK, Verity PG, Michaels AE, Davis LH (1987) Feeding by larval and post-larval ctenophores on microzooplankton. J Plankton Res 9:667-683

Sullivan BK, Reeve MR (1982) Comparison of estimates of the predatory impact of ctenophores by two independent techniques. Mar Biol 68:61-65

Sullivan LJ, Gifford DJ (2004) Diet of the larval ctenophore Mnemiopsis leidyi A. Agassiz (Ctenophora, Lobata). J Plankton Res 26:417-431

Underwood AJ, Chapman MG, Crowe TP (2004) Identifying and understanding ecological preferences for habitat or prey. J Exp Mar Biol Ecol 300:161-187

Vinogradov ME, Sapoznikov VV, Shushkina EA (1992) The Black Sea ecosystem. Nauka, Moscow (in Russian)

Vinogradova ZA (1964) Some biochemical aspects of the comparative study of plankton of the Black, Azov and Caspian Seas. Okeanologiya 4:232-242 (in Russian)

Waggett R, Castello TH (1999) Capture mechanisms used by the lobate ctenophore, Mnemiopsis leidyi, preying on the copepod Acartia tonsa. J Plankton Res 21:2037-2052

Winberg GG (1983) Vant-Goff temperature factor and the Arrhenius equation in biology. Zh Obschch Biol 44:31-42 (in Russian)

Yousefian M, Kideys AE (2003) Biochemical composition of Mnemiopsis leidyi in the southern Caspian Sea. Fish Physiol Biochem 29:127-131

Zaika VE, Revkov NK (1994) Anatomy of gonads and regime of spawning of Ctenophora Mnemiopsis sp. in the Black Sea. Zool J 73(3):5-10 (in Russian)

Zaika VE, Revkov N (1998) Ctenophora Mnemiopsis food in relation to zooplankton composition. Hydrobiol J 34(3): 29-36

Zaslavsky E (1980) The determination of the forms of carbon location in sea sediments. In: Romankevich EA (ed) Methods of investigation of organic matter in the ocean. Nauka, Moscow, p 121-128 (in Russian)

Submitted: June 1, 2004; Accepted: November 16, 2005 Proofs received from author(s): April 18, 2006 